\title{
'McJobs', 'good jobs' and skills: job-seekers' attitudes to low-skilled service work
}

Colin Lindsay, Employment Research Institute, Napier University, Edinburgh Human Resource Management Journal, Vol 15, no 2, 2005, pages 50-65

This article focuses on unemployed job-seekers' attitudes towards entry-level jobs in three areas of the service sector - retail, hospitality and call-centre work. The article examines whether job-seekers are reluctant to pursue these opportunities, and provides an analysis of the motives of those ruling out service work. A range of potential barriers is discussed, including the extent to which job-seekers perceive the service economy as offering only so-called 'McJobs' - low-skilled, low-paid jobs with few opportunities for development. However, the article also focuses on perceived skills mismatches, with some job-seekers arguably over-qualified for entry-level service jobs, while others consider themselves to lack the necessary 'soft' skills. The analysis is based on interviews with 220 unemployed people in Glasgow. The article concludes that policy action may be required to encourage job seekers to consider a broader range of vacancies and to provide tailored training in partnership with service employers. On the demand side, service employers must address the need for entry-level positions that offer realistic salaries, decent work conditions and opportunities for progression and development.

Contact: Colin Lindsay, Employment Research Institute, Napier University, Craiglockhart Campus, Edinburgh EH14 1DJ. Email: c.lindsay@napier.ac.uk

McJob: A low-pay, low-prestige, low-dignity, low-benefit, no future job in the service sector. Frequently considered a satisfying career choice by people who have never held one. Douglas Coupland: 'Generation $\mathrm{X}^{\prime}$

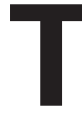

he rise of the 'service economy' has arguably emerged as the defining feature in the development of European labour markets during the post-war era. In the UK, by 2000, approximately 75 per cent of jobs were located in services (European Commission, 2001). Given the dominant role of services in delivering jobs growth, policy-makers have come to view attracting large-scale service employers as a key priority within strategies to regenerate declining, 'post-industrial' cities (Belt, 2002). Supply-side labour market policies such as the New Deal have also sought to link training to demand-led strategies meeting the recruitment needs of service employers (Fletcher, 2004).

Despite these developments, many cities, particularly in the north of the UK, continue to report labour and skills shortages in entry-level service work alongside high rates of unemployment and long-term unemployment. One suggested reason for this anomaly is that some forms of service work are unattractive to many job-seekers. Unemployed people can be reluctant to pursue what may be perceived to be - in the parlance of the novels of Douglas Coupland - 'McJobs': de-skilled, low-quality service jobs, which are viewed as offering poor pay and conditions and few opportunities for development (Lindsay and McQuaid, 2004). However, it has also been suggested that even where job-seekers are willing to target service occupations, many lack the skills 
required by service employers. Yet despite the continuing recruitment and retention problems reported by service employers, and the tenacity of localised unemployment in some areas, little detailed research has been carried out into the attitudes of unemployed job-seekers towards working in services and any barriers that these individuals may face to taking up such jobs. This article addresses these issues. The analysis is based upon interviews with 220 unemployed people in Glasgow.

Following this introduction, the next section briefly discusses the context for the research: the concept of 'good work', and how this ideal type differs from some analyses of low-skilled work in the service economy. This is followed by a summary of the study area, sample and methodology. Initial findings are reported on the occupational preferences of unemployed job-seekers and attitudes towards 'lowskilled' (ie entry-level) work in three areas of the service sector, before providing an analysis of the motives of those definitely ruling out these forms of service work. Finally, I draw conclusions and discuss implications for employers and policy-makers.

\section{IMPLICATIONS FOR JOB-SEEKING AND SKILLS}

\section{'Good jobs', ‘McJobs' and the rise of the service economy}

It should be noted that any attempt to discuss job-seekers' attitudes towards a homogeneous 'service sector' risks imposing a degree of generalisation that denies the term any real meaning. Even within Singlemann's (1978) generally accepted sub-sector classifications of distributive, personal, producer and social services, service work encompasses tasks ranging from administrative support to sales to more basic forms of 'personal services'. Nevertheless, it is clear that the increasing importance of serviceoriented work can be viewed as a source of problems as well as of opportunities. For Sassen (1996) the polarisation of workers' pay and conditions and the casualisation of employment relations that increasingly characterise work in urban labour markets are an inevitable consequence of the rise of the service economy; the growing importance of service inputs partially explains the increasing inequalities between workers in different sectors, while these inequalities are reproduced and accentuated within service work itself. Low-skilled service jobs tend to offer limited opportunities for progression, while levels of pay and shift working can also preclude workers from taking up training or engaging in networking that might otherwise provide alternative opportunities to move up the jobs ladder (Talwar, 2002). Meanwhile, traditional escape routes from poverty (such as the apprenticeship system) have disappeared (Charlesworth, 2000).

Sennett (1998) has extended this critique of the service economy to encompass the impact of service work on individuals' character and sense of self. For Sennett, 'old' forms of work organisation allowed for career-long progression, and a resulting sense of belonging and character. The constant need for career re-engineering and personal reinvention that is a key characteristic of the new service economy therefore threatens this sense of character; the ability to fashion not only a career but a sense of self and personal history through work has been lost. This, combined with the demand on service workers to engage in the representation and reproduction of emotional interactions ('emotional labour'), has, according to Sennett, imposed a 'demeaning superficiality' on relations at work.

The disappearance of 'good jobs' has potentially important consequences for worker satisfaction, recruitment and job-seeking, and (eventually) for productivity (Westwood, 2002). There is evidence that the low pay and lack of opportunities for development 
and advancement that define some service jobs can have an impact on the satisfaction and performance of workers (Brown and McIntosh, 2003). Given the apparent importance of job security (Ritter and Anker, 2002) and personal autonomy and empowerment (Rose, 2003) to satisfaction at work, the combination of insecurity of tenure and highly rationalised environments in some service workplaces may further undermine employee commitment. From the particular perspective of the study below, these issues surrounding access to 'good work' matter, because job-seekers' perceptions of the quality of jobs are likely to have an impact on their decisions to pursue, accept and sustain different types of employment. It is clear that job satisfaction, for those in work, is a predictor of whether individuals quit or stay in jobs (Clark et al, 1998). It has also been shown that perceived potential satisfaction at work is associated with labour market re-entry by job-seekers (Clark, 1997). Their fears over the quality and stability of service work may therefore conversely result in a reluctance to pursue these opportunities (McQuaid and Lindsay, 2002).

\section{Skills and job-seeking in the service economy}

Despite these concerns, there is little doubt that many policy-makers view service industries - and particularly those involving labour-intensive, low- to medium-skilled work - as providing an important opportunity for employment creation. Yet, as noted above, many urban areas continue to report both pockets of high unemployment and recruitment and retention problems in the service sector. Webster (2000) argues that the reason for this contradiction can be understood as a function of changing skills demands and perceived job roles: job-seekers formerly employed in traditional sectors have neither the skills nor the desire to take up the 'white collar' service employment that has replaced unskilled manual work. Such negative attitudes to service work may also be passed on to the (especially male) children of these former manual industrial workers (McDowell, 2002).

The real and perceived skills required to undertake service work may require further discussion at this point. Traditional definitions of skill have come under increasing pressure in recent years, as the need to understand the competencies required by service work has been acknowledged (Grugulis, 2003). Although, as we have seen above, it has been argued that the shift towards a service economy has led to large-scale de-skilling, service work does require a range of skills, especially 'soft skills' such as communication and team working. These soft skills, and even more basic personal attributes such as appearance and attitudes, have increasingly featured as a target for training policy. This broadening of the concept of skill has therefore had profound consequences for how people are developed and managed at work (justifying control and instruction over a much wider range of behaviour) and the content of supply-side labour market interventions (Grugulis et al, 2004). The resulting refocusing of training policy on generic 'employability' skills and key 'competencies' fits well with UK policy-makers' pursuit of flexibility and pragmatic labour market interventions, but has also arguably contributed to a continuing neglect of general education.

Furthermore, while the process of redefining skills to reflect the needs of the service economy may, to an extent, see a process by which previously under-valued abilities are now recognised, these skills tend to be both poorly defined and unaccredited. Although highly transferable at certain levels of the service sector, such skills carry little broader status, reflecting the general lack of status afforded to female-dominated work (Talwar, 2002). They are also rarely formalised in training that offers structured career progression (Webster, 2004), and attract virtually no wage premium (Felstead et 
al, 2002). 'This is skill as a rhetorical device that carries no material benefits' (Grugulis et al, 2004: 12).

What is clear is that the skills sets demanded by service employers, whether soft skills in sectors such as retail and tourism or ICT literacy in so-called 'MacJobs' or 'i-MacJobs' such as teleservicing (Goos and Manning, 2003; Nickson et al, 2003), are unfamiliar to many former manual workers with experience in, for example, manufacturing or construction. There is also evidence that employers involved in customer-facing service activities can discriminate against older male job-seekers, the long-term unemployed and others considered 'unsuitable', given the demands of aesthetic labour (ie looking or sounding 'right'). Warhurst and Nickson (2001) note that the redefinition of skills to encompass communication, presentation and interpersonal factors may reinforce broader labour market inequalities; these softer skills are often closely linked to self-confidence, which in turn can reflect social class and educational attainment. Indeed, there is already evidence that a substantial student labour force has emerged, with young people in higher education taking positions in hospitality and retail that might otherwise be open to the lower skilled. Again, it has been suggested that employers in these sectors prefer the flexibility and soft skills demonstrated by these student workers (Hofman and Steijn, 2003). Finally, while male job-seekers (who dominate the unemployed claimant count) can hold views of their position in the labour market that are strongly 'gendered', service employers tend to target women anyway, as they are more likely to accept part-time work and are perceived to offer the type of skills (especially in terms of emotional labour) that are often a prerequisite for service work (McDowell, 2002).

The implications of unemployed job-seekers being excluded, or excluding themselves, from entry-level service work are serious. Those who, already facing other forms of labour market disadvantage, rule out, or are turned away from, growing sectors of the economy may be more likely to fall victim to long-term unemployment as a result. These job-seekers will also be excluded from the positive benefits that can be associated with a return to work, even low-skilled service work. As Newman (1999) notes, even the lowest-skilled service work can, in the right circumstances, offer individuals benefits in terms of self-sufficiency and the dignity of work, and the opportunity to develop a range of competencies. Given the lack of emphasis on formal qualifications, many areas of the service sector can provide the opportunity for unqualified or initially low-skilled workers to progress towards promoted positions (Burkitt, 2001). Edwards and Burkitt (2001) have also suggested that, while low pay remains a serious problem for service workers, getting paid at all is seen as a key benefit by these individuals.

This is not to discount the broader problems associated with 'quality of work' in some areas of the service sector. Yet here, too, there is evidence that service workers can develop sophisticated coping strategies to deal with the sense of alienation that might otherwise result from routinised, customer-facing job roles (Korczynski, 2003). It would appear that workers can also benefit from the emotional interaction at the heart of service relationships, particularly if required to express diverse affective responses when dealing with customers across a range of different settings and service scenarios (Brotheridge and Grandley, 2002). Despite the arguable lack of 'good jobs' in serviceoriented sectors, many workers have demonstrated the capacity to handle the 'psychological balancing act' of delivering emotional and aesthetic labour in rationalised work settings (Bulan et al, 1997), while also developing coping strategies to deal with the consequences of low pay and insecurity - just as those previously engaged in the traditional forms of work so valued by Sennett (1998) developed 
strategies to cope with monotonous toil that was the reality of these low-skilled workers' everyday lives (McDowell, 2003; Lindsay and McQuaid, 2004).

Entry-level service jobs can provide a route out of poverty and a first step on the skills ladder for the unemployed. However, if these occupations are to provide a realistic employment and training goal for job-seekers, the barriers preventing people from pursuing service work must be understood. To what extent have concerns regarding the quality and stability of work in the service economy resulted in unemployed people seeking to avoid these occupations? What evidence is there of a mismatch between the perceived skills and experience of job-seekers and the demands of customer-facing service work? Which groups of job-seekers are most likely to rule out service work and why? And what are the implications for employers, job-seekers and policy-makers?

\section{METHODOLOGY AND SAMPLE}

The research was carried out in Glasgow, Scotland's largest city (and the UK's fourth largest), with a working age population of approximately 370,000 . The city is located in Scotland's 'central belt' and is a major investment and employment hub, accounting for approximately 15 per cent of Scottish GDP (Scottish Executive, 2001). Despite Glasgow's history as a major centre of manufacturing, recent years have seen a significant shift towards service employment. Service jobs account for 87 per cent of employment (well above the Scottish average of 80 per cent), and the city reported a 22 per cent increase in services between 1995 and 2003 (Scottish Executive, 2004). In terms of occupational profile, low- to medium-skilled service positions make up an important element in the Glasgow labour market. At the time of the research (April-May 2003), protective, caring, other personal, and customer services accounted for 30 per cent of vacancies notified to Jobcentres in the relevant travel-to-work-area. When 'elementary administrative and other services' are added, the proportion rises to well over 50 per cent. The particular importance of the socalled 'style labour market', with opportunities concentrated in high-end retail and hospitality outlets, has also been noted as a defining feature of Glasgow's expanding service sector (Nickson et al, 2003).

However, in recent years unemployment has remained above the national average. At the time of the research, registered claimant unemployment was 4.8 per cent, compared with Scottish and UK averages of 3.2 per cent and 2.6 per cent, respectively. Furthermore, claimant unemployment figures mask a more serious problem of pockets of long-term economic inactivity, with large numbers claiming non-work- related benefits - at the time of the research, 110,000 Glasgow residents (more than a quarter of the working age population) were claiming benefits of some kind, with two-thirds of these people registered for sickness-related benefits. A recent estimate placed the 'real level of unemployment' (non-voluntary economic inactivity among those willing to work) at 22 per cent (Beatty et al, 2002).

The research was carried out in two areas of Glasgow: Auldhouse in the south-west, and Springburn in the north of the city. Both areas report above-average levels of unemployment and economic inactivity. Structured, face-to-face interviews were carried out with 220 registered unemployed people at Jobcentre offices in the two areas. The sample accurately reflected the gender balance within the registered unemployed population in Glasgow (80 per cent men and 20 per cent women). The age profile of the sample also reflected the wider registered unemployed population reasonably accurately. Approximately 27 per cent of the sample were in the 16-24 age group 
(compared with 24 per cent of the Glasgow claimant count), 60 per cent were in the 'core' job seeker age group of 25-49 (compared with 59 per cent of the claimant count), and 13 per cent were aged 50 and over (compared with 17 per cent).

However, the long-term unemployed were deliberately over-represented, to ensure a usable sample for comparing the barriers faced by these and more recently unemployed job-seekers. Approximately a third (33 per cent) of interviewees had been unemployed for more than a year, compared with 16 per cent of Glasgow's registered unemployed. Finally, the educational attainment of both long-term and short-term jobseekers within the sample was relatively limited. For example, 64 per cent of all respondents were not qualified to SCE Higher Grade level ('A-Level' or NVQ Level 3 equivalent), rising to 74 per cent among the long-term unemployed. Competing in a Scottish labour market in which only 43 per cent of workers are similarly unqualified (Futureskills Scotland, 2003), these job-seekers will be at a clear disadvantage.

\section{JOB-SEEKERS' ATTITUDES TOWARDS SERVICE WORK}

It is to be expected that individuals' skills profiles and previous experience in the labour market will have an impact upon their job search targets, and therefore upon their attitudes towards service vacancies. An analysis of Glasgow respondents' previous regular occupations reveals, perhaps predictably, a below-average skills profile and high proportions involved in various forms of manual work. More than a quarter of respondents (26 per cent) reported their previous regular occupation as involving broadly unskilled manual work. A further 23 per cent (in total) had worked in skilled manual, craft-related or machine operations work. In comparison, only 30 per cent had regularly worked in personal or other services (17 per cent) or retail and customer services (13 per cent). Former service workers tended to be relatively poorly qualified. Service workers made up 37 per cent of respondents who were not qualified to SCE Higher Grade/NVQ 3 or equivalent, compared with only 17 per cent of those who had attained at least that level of qualification. The manner in which men dominate the claimant unemployed (and so this sample of job-seekers) means that it is difficult to draw out gender differences given a limited number of women respondents. Nevertheless, women were predictably over-represented in services (32 per cent of all former service workers, compared with 20 per cent of the total sample). Service workers also had a slightly younger age profile - 54 per cent were aged 17-34, compared with 46 per cent of the total sample.

Table 1 compares respondents' former regular and sought occupations (ie their main job search targets). The similarity between the two sets of figures is striking. Again, a minority of respondents cited service positions as being their main focus (this time, 31 per cent in total). Again, almost half of respondents named manual, craftrelated or machine-operating occupations (this time, 47 per cent in total). Further analysis revealed that the vast majority of respondents were indeed targeting the same or similar occupations to their former regular employment. These findings concur with previous research on the tenacity of job-seekers' main search targets - a phenomenon that can prove problematic in areas where many among the unemployed were formerly employed in now declining industrial sectors (McQuaid and Lindsay, 2002). Nevertheless, it is unsurprising that job-seekers were primarily targeting sectors and occupations where previously they had enjoyed success in finding work.

Problems will arise, however, where unemployed people (and particularly those with limited skills) are not willing at least to consider other forms of work - 
TABLE 1 Respondents' previous regular occupations and primary sought occupations

\begin{tabular}{lcc|} 
Occupational group & Regular occupation & Sought occupation \\
Professional/associate professional & 8 & 11 \\
Skilled manual and craft-related & 19 & 16 \\
Plant and machine operators & 4 & 3 \\
Clerical and administrative & 10 & 10 \\
Personal and other services & 17 & 18 \\
Retail and customer services & 13 & 13 \\
Unskilled manual & 26 & 28 \\
None/never worked/don't know & 3 & 1 \\
Total (\% rounded) & 100 & \\
& & \\
$\mathrm{~N}=220$ & &
\end{tabular}

especially accessible, entry-level occupations in growing sectors. Accordingly, respondents were asked whether they would rule out, or be willing to consider, entry-level jobs in three areas of the service sector. Generic job roles rather than specific occupations were suggested - the objective being to tease out job-seekers' general feelings towards key areas of the service economy, rather than asking them to consider particular vacancies. The three areas discussed were retail, hospitality (eg reception or bar work) and teleservicing or 'call-centre work'. These broad occupational sectors were selected given the importance of both retail and leisure and hospitality to the labour market in Glasgow and other UK cities. The call-centre sector has also emerged as an important source of employment in Glasgow, currently employing approximately 10,000 people.

As Table 2 shows, more than two-fifths (43 per cent) of interviewees said they would never, under any circumstances, consider retail work. This compares with only 13 per cent who were likely to consider applying for such jobs. Hospitality occupations were similarly unpopular - ruled out by 47 per cent of job-seekers, and actively considered by only 9 per cent. A far larger proportion of interviewees said that they would never consider call-centre jobs (68 per cent), while only 2 per cent viewed themselves as likely to consider such positions. Thus, even the most basic analysis demonstrates that

TABLE 2 Percentage who would consider work in selected entry-level service occupations

\begin{tabular}{|llccc|}
\hline $\begin{array}{l}\text { Occupational } \\
\text { sector }\end{array}$ & $\begin{array}{l}\text { Never } \\
\text { consider }\end{array}$ & $\begin{array}{l}\text { Possibly } \\
\text { consider }\end{array}$ & $\begin{array}{l}\text { Likely to } \\
\text { consider }\end{array}$ & $\begin{array}{l}\text { Don't know/ } \\
\text { no response }\end{array}$ \\
Retail & 43 & 41 & 13 & 3 \\
Hospitality & 47 & 41 & 9 & 3 \\
Call-centre & 68 & 27 & 2 & 3 \\
$\mathrm{~N}=220$ & & & & \\
\hline
\end{tabular}


TABLE 3 Percentage of respondents ruling out entry-level work in retail, hospitality and call-centre sectors, by selected respondent characteristic

\begin{tabular}{|c|c|c|c|}
\hline Respondent characteristic & $\begin{array}{l}\text { Retail } \\
\%\end{array}$ & $\begin{array}{l}\text { Hospitality } \\
\%\end{array}$ & $\begin{array}{l}\text { Call centres } \\
\%\end{array}$ \\
\hline Male (female) & $46(32)$ & $53(23)^{* *}$ & $69(64)$ \\
\hline Aged 50 and over (under 50) & $62(39)^{* *}$ & $68(43)^{* *}$ & $78(66)$ \\
\hline Aged under 25 ( 25 and over) & $26(51)^{* *}$ & $17(57)^{* *}$ & $60(70)$ \\
\hline Regular occupation in services (not in services) & $28(50)^{* *}$ & $26(57)^{* *}$ & $65(69)$ \\
\hline $\begin{array}{l}\text { Qualified to SCE Higher Grade/A-Level/ } \\
\text { NVQ } 3 \text { equivalent (not qualified to this level) }\end{array}$ & $54(37)^{*}$ & $56(42)$ & $63(70)$ \\
\hline Rated interpersonal skills 'good' ('not good') & $43(42)$ & $48(47)$ & $68(72)$ \\
\hline Dependent children (no dependent children) & $58(40)^{*}$ & $63(44)^{*}$ & $70(68)$ \\
\hline Seeking $£ 200$ weekly wages (less than $£ 200$ ) & $52(36)^{*}$ & $56(39)^{*}$ & $73(63)$ \\
\hline $\begin{array}{l}\text { Would consider part time (wouldn't consider) } \\
\mathrm{N}=220 \\
{ }^{*} \text { Significant at } 5 \% \text { level } \\
{ }^{*} \text { Significant at } 1 \% \text { level }\end{array}$ & $41(45)$ & $43(51)$ & $68(68)$ \\
\hline
\end{tabular}

substantial minorities of respondents ruled out key areas of the service economy such as retail and hospitality from their job search, while well over two-thirds would not consider call-centre vacancies.

Further consideration of 'who ruled out service jobs' reveals a number of significant differences between job-seeker groups - at least in the retail and hospitality sectors. First, it is clear that the widely expressed concern that older male job-seekers are unlikely to pursue such jobs is to some extent justified. As Table 3 illustrates, men were clearly more likely to rule out retail work (46 per cent compared with 32 per cent of women). Men were also significantly (1 per cent level using chi-square test) more likely to rule out hospitality jobs (53 per cent compared with 23 per cent). When the sample was split into 50 and over and 25 and under age groups, statistically significant differences (1 per cent level) between job-seekers' views on retail and hospitality work were again observed. For example, whereas 68 per cent of the 50-plus age group were unwilling to consider, under any circumstances, entry-level hospitality posts, the figure was only 43 per cent for under-50s.

Two measures of skills attainment were deployed to compare the reluctance of jobseekers with different skills sets to consider entry-level service employment: whether qualified to SCE Higher Grade/NVQ 3 or equivalent; and regular experience in customer-related service work, as a proxy for the soft skills required for service jobs. Work experience in a given sector does not necessarily imply the attainment of specific skills. However, service skills are often unaccredited, so that job-seekers' identification of their 'main' or regular occupation as involving customer-facing services may offer the only indicator that their skills are concentrated here. At a practical level, the regular and sought occupations reported by job-seekers are used by Jobcentre advisers (applying Standard Occupation Codes) to identify appropriate vacancies, so that occupational background is in effect regularly used as a proxy for job-seekers' area of skill within the job-matching process. Higher-qualified jobseekers were more likely to reject both hospitality and retail jobs (in the latter case the 
difference was significant at the 5 per cent level). More strikingly, interviewees with previous experience in, and arguably therefore the appropriate skills to carry out, service jobs were significantly less likely (1 per cent level) to rule out work in hospitality and retail.

Interviewees were also divided according to their willingness to consider part-time work, their family circumstances and their minimum reservation wage - three potential indicators of the flexibility that job-seekers were likely to be able or willing to demonstrate when identifying opportunities. Ruling out part-time work was not a statistically significant indicator of a broader unwillingness to consider service jobs. Nevertheless, the general reluctance of job-seekers to consider part-time work may still act as a barrier to pursuing many service positions - 61 per cent of all respondents ruled out all part-time jobs. The majority of these reported concerns regarding housing costs and the loss of 'passported' housing-related benefits (payable to the long-term unemployed and inactive, linked to the receipt of other income-based benefits), which meant that finding stable, full-time work was a particular priority.

Those with family/caring responsibilities were significantly more likely ( 5 per cent level) to rule out service jobs -58 per cent of those with dependent children would not consider retail opportunities, compared with 40 per cent of other job-seekers. Similarly, 63 per cent of people with children ruled out entry-level hospitality jobs (compared with 44 per cent of other job-seekers). It would appear that the long hours culture and low pay that has come to be associated with these forms of service employment may act as a barrier for people with the additional caring and financial responsibilities of children. Certainly, levels of pay apparently remain an issue - those seeking net wages in excess of $£ 200$ per week were significantly more likely (5 per cent level) categorically to rule out both retail jobs (52 per cent compared with only 36 per cent of those willing to accept wages below £200) and hospitality work (56 per cent compared with 39 per cent).

Finally, the call-centre sector appears to be a 'special case'. None of the significant differences reported between job-seeker groups' attitudes towards retail and hospitality jobs were apparent when it came to call-centre work. There were some quite clear differences between respondents' views, with those aged 25 and over more likely to rule out such work (70 per cent compared with 60 per cent of younger job-seekers), and people seeking at least $£ 200$ as a net weekly wage similarly reluctant to consider these jobs (73 per cent compared with 63 per cent). However, even these differences were not statistically significant. The differences between the proportion of all job-seekers ruling out call centres compared with other forms of service work were more significant than any differences among job-seeker sub-groups - recall that 68 per cent of all interviewees refused to consider call-centre jobs, compared with only 47 per cent and 43 per cent ruling out the hospitality and retail sectors, respectively.

It would appear that negative perceptions regarding conditions in the call-centre sector may have affected the choices made by unemployed job-seekers. Many interviewees offered negative opinions of the highly pressurised work conditions in call centres. Few of these views were based on direct experience (see below), but there is little doubt that call centres provide a particularly rigorous manifestation of the 'industrialisation of service sector work' (Taylor et al, 2003). It may be that information about the sector's reputation for combining challenging work conditions with relatively low levels of financial reward, and the high levels of absenteeism and turnover that often follow, has 'filtered down' to job-seekers. The result appears to have been a broadly shared, largely negative view of call-centre work, commonly held across a range of job-seeker groups. 
TABLE 4 Main reason given by respondents for ruling out service jobs (\%)

\begin{tabular}{|lccc|}
\hline Stated reason & $\begin{array}{c}\text { Retail } \\
\%\end{array}$ & $\begin{array}{c}\text { Hospitality } \\
\%\end{array}$ & $\begin{array}{c}\text { Call centres } \\
\%\end{array}$ \\
Specifically targeting other sectors & 40 & 38 & 21 \\
Lack of appropriate skills & 16 & 14 & 32 \\
Unsuited to dealing with customers & 14 & 8 & 5 \\
Type of work/work environment & 11 & 10 & 32 \\
Low pay & 8 & 10 & 5 \\
Health reasons & 6 & 8 & 3 \\
Shift work & 3 & 9 & 1 \\
Insecurity & 0 & 1 & 0 \\
'Women's work' & 1 & 1 & 0 \\
Don't know & 1 & 2 & 1 \\
Total (\% rounded) & 100 & 100 & 149 \\
N & 95 & 104 & \\
\hline
\end{tabular}

\section{Reasons for ruling out service jobs}

Beyond the call-centre sector, demographic characteristics, skills and experience, family commitments and wage flexibility all emerged as significant factors associated with job-seekers categorically ruling out entry-level service jobs. In order to investigate further how and why the decision to rule out service jobs was made, those who were unwilling to consider entry-level work in retail, hospitality and teleservicing were asked about their motives. As Table 4 illustrates, interviewees cited a variety of reasons when asked to name the single most important factor leading to their ruling out service jobs (note that in all cases the sample is restricted to those who would 'never consider' these positions). Of those ruling out retail and hospitality work, approximately twofifths (40 per cent in retail and 38 per cent in hospitality) said that they were concentrating their job search on other occupations. This particularly applied to the higher skilled, and was also a disproportionately popular response among male jobseekers. In the vast majority of cases, these people had worked mainly in other sectors - less than one-tenth of those ruling out retail or hospitality jobs because they were targeting other occupations had regularly worked in services.

The 'positive' reason of 'targeting other sectors' was less commonly cited by those ruling out call-centre work (21 per cent). It is as notable that concerns about the 'quality of work/work environment' provided a far more popular reason for ruling out entrylevel call-centre jobs (32 per cent compared with 11 per cent and 10 per cent of those ruling out retail and hospitality, respectively). Again, perceptions of the call-centre sector as offering a strictly controlled, highly pressurised work environment appear to have had an impact on job-seekers' decisions. It is perhaps surprising that specific concerns over pay and job security were not more prevalent. Only one respondent across all three sectors cited job insecurity as the key factor influencing their decision to reject service work (in this case, in the hospitality sector). Across all three sectors, 5-10 per cent of job-seekers said that low pay had crucially affected their decision to rule out service jobs. Of course, the decision to 'target other sectors' may be informed by a range of factors, and the relationship identified above between wage demands and 
TABLE 5 Key factors influencing respondents' decision to rule out service jobs

\begin{tabular}{|lccc|}
\hline Main influencing factor & $\begin{array}{c}\text { Retail } \\
\%\end{array}$ & $\begin{array}{c}\text { Hospitality } \\
\%\end{array}$ & $\begin{array}{c}\text { Call centres } \\
\%\end{array}$ \\
Direct personal experience & 16 & 14 & 7 \\
Direct experience of contacts & 6 & 11 & 20 \\
'Common knowledge' & 33 & 32 & 47 \\
Targeting other jobs/no specific factor & 45 & 43 & 26 \\
Total (\% rounded) & 100 & 100 & 100 \\
N & 95 & 104 & 149 \\
& & & \\
\hline
\end{tabular}

ruling out service work suggests that pay rates in these sectors remain problematic for many job-seekers.

Finally, skills issues do matter when seeking to explain why job-seekers rule out certain occupations. Approximately 30 per cent of those who would not consider retail jobs gave 'a lack of appropriate skills' (16 per cent) or that they were 'not suited to dealing with customers' (14 per cent), a reflection of a real or perceived lack of interpersonal skills, as their main reasons. Of those rejecting hospitality jobs, 22 per cent in total identified skills issues as their main motivation (14 per cent considering that they lacked appropriate skills, and 8 per cent citing concerns over dealing with the public). Skills gaps were even more important in explaining negative attitudes towards call-centre work - 32 per cent of those refusing to consider teleservicing jobs did so mainly because they thought that they lacked the necessary skills (with ICT and 'telephone' skills regularly mentioned by job-seekers). A further 5 per cent raised concerns regarding their ability to deal with customers.

Thus, the desire to target familiar occupations, perceived skills gaps and (especially with regard to call-centre jobs) concerns about the quality of the working environment were the key factors explaining job-seekers' reluctance to consider entry-level service positions. However, in order to understand the basis for decisions to rule out certain areas of the service economy, and plan policy interventions in response, it is also important to identify the sources informing job-seekers' attitudes. Accordingly, interviewees were asked about factors influencing their decisions to reject certain service jobs. As Table 5 shows, those who had earlier explained their decision to reject service jobs on the basis that they were 'targeting other sectors' effectively ruled themselves out of this question - in many cases, their positive experiences in other jobs were the main factor influencing their decision to reject service work. A smaller number of job seekers also insisted that 'no specific factor' had informed their decisionmaking. Among those who were able to identify a single, key factor influencing their decision to reject such jobs (in most cases, having previously cited 'negative' reasons for ruling out service work such as a lack of skills or perceptions of the work environment), a minority mentioned their own experiences of these forms of work. Only 16 per cent of those ruling out retail work and 14 per cent of those rejecting hospitality jobs did so on the basis of their previous experience in such occupations. Call-centre jobs - ruled out by more job-seekers, and more often for 'negative' reasons were rejected on the basis of personal experience by only 7 per cent of those refusing to consider these positions. In contrast, those ruling out call-centre jobs more often cited the negative experiences of personal contacts. 
It is notable that almost a third of those ruling out retail and hospitality jobs (33 per cent and 32 per cent, respectively) and almost half of those who would not consider teleservicing (47 per cent) did so on the basis of what was often described as 'common knowledge'. The view was that 'everyone knows' about the disadvantageous pay and conditions associated with such service jobs, or the specific interpersonal or ICT skills that these jobs require (and that some job-seekers considered themselves to lack). There may be some encouragement here for service employers and policy-makers concerned with matching job-seekers to opportunities in the labour market. The vast majority of those rejecting service opportunities had arrived at this decision because of their determination to pursue opportunities in other sectors (in most cases, having not worked in services) or on the basis of 'common knowledge', rather than first-hand experience. An optimistic reading of these findings might be that job-seekers' hostility towards entry-level service jobs may turn out to be 'a mile wide, but an inch deep' based on a vague sense of animosity towards certain types of non-traditional work, a lack of confidence in their own skills, and a lack of knowledge regarding the range of opportunities within the service economy. Of course, a less optimistic analysis would point to the regularity with which service jobs were categorically excluded from individuals' search strategies, and the extent to which these attitudes reflect a deeper problem of locating 'good jobs' in the service economy; there may be an underlying awareness that the opportunities to progress towards better-paid, stable employment once provided by even entry-level jobs in traditional sectors are less likely to be found in services.

\section{MAKING A LIVING INTHE SERVICE ECONOMY}

Who invented these McJobs anyway?

They're work, but they're not a living.

Douglas Coupland: 'Shampoo Planet'

It has been suggested that, for many unemployed people, entry-level service work continues to be associated with so-called 'McJobs' - low-skilled jobs that offer the prospect of access to work, but rarely the genuine opportunity to 'make a living' and develop sustainable career paths. The above findings suggest that concerns over the reluctance of many job-seekers to consider entry-level service work are justified. Older, male job-seekers, those without experience in service occupations, people with caring responsibilities, and those seeking higher wages were significantly more likely to rule out service jobs. In total, more than two-fifths of interviewees would not consider applying for entry-level retail or hospitality jobs under any circumstances. Almost 70 per cent ruled out call-centre work, and 73 per cent of all interviewees ruled out at least one of the three service occupations under discussion.

Job-seekers' negative views of service work may have led many to eliminate these jobs completely from their search strategies. However, real and perceived skills gaps clearly also have a role to play in explaining why some job-seekers rule out service work. In some cases, the decision to rule out these jobs was partly or mainly based on assumptions regarding the skills required to do service work - skills that job-seekers perceived themselves not to possess. Certainly, there was evidence of skills gaps being seen as a major barrier by job-seekers, expressed in general terms or in relation to being 'unsuited to dealing with customers'. A lack of practical experience in customer-facing job roles was also a defining characteristic of many of those ruling out services. These 
findings support the conclusions of earlier qualitative research focusing on Glasgow job-seekers' views of the three sectors discussed above, which found evidence of a lack of detailed knowledge regarding the skills required to do service jobs, and a general perception among the long-term unemployed that they were unsuited to these positions (TERU, 1999).

Given the importance of recent and relevant work experience to individuals' employability, an expansion of service-oriented training programmes for job-seekers may be of value. If a lack of relevant experience, and real and perceived skills gaps, are indeed behind job-seekers' unwillingness to consider entry-level service jobs, then targeted, placement-based training within supportive 'real work' settings may help individuals make the transition to work in otherwise unfamiliar service environments. Policy-makers are belatedly focusing on the development of such programmes. Innovative supply-side initiatives in Glasgow have shown that long-term unemployed people are receptive to service training and have the ability to develop a sophisticated awareness of the demands of aesthetic and emotional labour (Nickson et al, 2003).

However, the delay in developing training initiatives to help the unemployed to access service work reflects a more general debate relating to the definition of skills held by policy-makers and service providers. In the eyes of many, entry-level service jobs remain an example of inherently rationalised, de-skilled work (Bradley et al, 2000). As noted above, such an approach does not account for the complex range of emotional, aesthetic and organisational skills that define different forms of service employment, but the problem remains that many of these skills are largely unaccredited and unrewarded. There is also little evidence of formal structures enabling entry-level workers in sectors such as retail, hospitality and teleservicing to develop a broader range of skills and qualifications and thus secure progression towards higher-paid positions.

This is likely to have an impact on job-seekers' attitudes towards these sectors. Within our sample, job-seekers with experience in industries characterised by strong, formalised progression and training routes continued to favour these areas of work, despite the decline of opportunities in traditional sectors and the growth of the service economy. It may be that many of those 'specifically targeting other sectors' (and ruling out service jobs) were determined again to find work offering the potential for advancement, skills development and long-term financial stability. Employers may need to make a more convincing case that there are adequate opportunities for development and advancement within their organisations if these job-seekers are to be convinced to 'take a risk' on service work. Measures to develop clearer, formalised career progression routes should therefore be a priority for major service employers and representative bodies such as Sector Skills Councils. In particular, given the importance of perceived skills gaps to some job-seekers, a commitment by employers to work towards the accreditation of skills and the formalisation and further development of training procedures may have a significant incentive effect.

The broader issues raised by job-seekers with regard to the 'quality of the work environment' (with call centres proving a source of particular concern) also require action on the part of employers. Whether based on 'common knowledge' or direct experience, many unemployed people perceive call centres as offering a highly pressurised, tightly controlled and deeply unsatisfying work experience. There is considerable evidence to support job-seekers' judgements in this area (Belt, 2002; Deery and Kinnie, 2002; Taylor et al, 2003). Turnover among call-centre operators, and the other service occupations discussed above, is well above average. If service employers are to address the recruitment and retention problems they face, there must be a 
renewed commitment to following through with measures to promote what the UK government has called a 'minimum infrastructure of decency and fairness around people in the workplace' (DTI, 1998).

Similarly, employers are likely to continue to face recruitment and retention problems for as long as low pay acts to prevent those without other, additional means of support from considering entry-level service work. Three key entry-level occupations in the hospitality sector (hotel, restaurant and bar work), along with retail jobs, make up four of the five lowest-paying occupational categories in the UK labour market (Bulman, 2003). The pay rates offered by employers effectively forced many among our sample of job-seekers to reject entry-level service work. For example, 30 per cent of those who named a minimum acceptable net weekly wage said that they required at least $£ 250$ after all deductions; more than 90 per cent said that they required at least $£ 125$. By comparison, for example, the average gross weekly wage (before deductions) among 'sales assistants and retail cashiers' in Glasgow at the time of the research was approximately $£ 245$ for full-time and $£ 103$ for part-time workers (ONS, 2004). As Klein (2000: 232) has noted, referring to the US context, an assumption appears to have grown up that entry-level service jobs need not provide for essentials such as housing and food, as they are most likely to be used to secure an additional income for students or second earners (in most cases, women): 'These are great jobs, in other words, for people who don't really need them'. Service employers will struggle to attract those seeking to support themselves and their families through full-time work while this attitude prevails. From the policy perspective, measures such as the National Minimum Wage and Working Tax Credit have raised the earnings of entrylevel service workers. The continuation and strengthening of such measures will be necessary if policies to promote the transition from welfare to work in the service economy are to continue to prove justifiable and workable.

The reality is that a combination of measures is required to provide job-seekers with appropriate skills while also making service work a more attractive, or at least realistic, option for the unemployed. Training initiatives acknowledging and addressing the complex skills sets required by service employers are to be welcomed. At the same time, action on the part of employers and policy-makers to formalise and accredit these skills, and improve pay and progression routes, must be central to efforts to use the growth of the service economy as a source of new opportunities for unemployed jobseekers. If the unemployed are to be encouraged to take up these opportunities, there must be a renewed commitment on the part of employers and policy-makers to delivering 'good jobs' in the service economy - jobs that offer realistic wages, decent conditions and the kind of opportunities for personal development and advancement that are available to workers across a range of other sectors.

\section{REFERENCES}

Beatty, C., Fothergill, S., Gore, T. and Green, A. (2002). The Real Level of Unemployment, Sheffield: Sheffield Hallam University.

Belt, V. (2002). 'A female ghetto? Women's careers in call centres'. Human Resource Management Journal, 12: 4, 51-66.

Bradley, H., Erickson, M., Stephenson, C. and Williams, S. (2000). Myths at Work, Cambridge: Polity Press.

Brotheridge, C. M. and Grandley, A. A. (2002). 'Emotional labor and burn-out: comparing two perspectives of "people work"'. Journal of Vocational Behavior, 60: 1, 17-39. 
Brown, D. and McIntosh, S. (2003). 'Job satisfaction in the low wage service sector'. Applied Economics, 35: 10, 1241-1254.

Bulan, H. F., Erickson, R. J. and Warton, A. S. (1997). 'Doing for others on the job: the affective requirements of service work, gender and emotional well-being'. Social Problems, 44: 2, 235-256.

Bulman, J. (2003). 'Patterns of pay: results of the 2003 New Earnings Survey'. Labour Market Trends, 111: 12, 601-612.

Burkitt, N. (2001). A Life's Work: Achieving Full and Fulfilling Employment, London: Institute for Public Policy Research.

Charlesworth, S. (2000). A Phenomenology of Working Class Experience, Cambridge: Cambridge University Press.

Clark, A. (1997). 'Job satisfaction and gender: why are women so happy at work?'. Labour Economics, 4: 4, 341-372.

Clark, A., Georgellis, Y. and Sanfey, P. (1998). 'Job satisfaction, wages and quits: evidence from German panel data'. Research in Labor Economics, 17, 95-121.

Coupland, D. (1992). Generation X, London: Abacus.

Coupland, D. (1993). Shampoo Planet, London: Simon and Schuster.

Deery, S. and Kinnie, N. (2002). 'Call centres and beyond: a thematic evaluation'. Human Resource Management Journal, 12: 4, 3-13.

DTI (Department for Trade and Industry) (1998). Fairness at work, London: DTI.

Edwards, L. and Burkitt, N. (2001). 'Wanting more from work? Expectations and aspirations of people in low and middle-paid jobs'. Labour Market Trends, 109: 7, 375378.

European Commission (2001). Employment in Europe 2001, Brussels: European Commission.

Felstead, A., Green, F. and Gallie, D. (2002). Work Skills in Britain 1986-2001, Nottingham: Stationery Office.

Fletcher, D. R. (2004). 'Demand-led programmes: challenging labour market inequalities or reinforcing them?'. Environment and Planning C: Government and Policy, 22: 1, 115-128.

Futureskills Scotland (2003). Scottish Labour Market Report 2003, Glasgow: Futureskills Scotland.

Goos, M. and Manning, A. (2003). 'McJobs and Macjobs: the growing polarisation of jobs in the UK', in R. Dickens, P. Gregg and J. Wadsworth (eds), The Labour Market under New Labour, Basingstoke: Palgrave.

Grugulis, I. (2003). 'Putting skills to work: learning and employment at the start of the century'. Human Resource Management Journal, 13: 2, 3-12.

Grugulis, I., Warhurst, C. and Keep, E. (2004). 'What's happening to "skill"?', in C. Warhurst, I. Grugulis and E. Keep (eds), The Skills That Matter, Basingstoke: Palgrave.

Hofman, W. H. A. and Steijn, A. J. (2003). 'Students or lower skilled workers? Displacement at the bottom of the labour market'. Higher Education, 45: 2, 127-146.

Keep, E. and Mayhew, K. (1999). 'The assessment: knowledge, skills and competitiveness'. Oxford Review of Economic Policy, 15: 1, 1-15.

Klein, N. (2000). No Logo, London: Flamingo.

Korczynski, M. (2003). 'Communities of coping: collective emotional labour in service work'. Organisation, 10: 1, 55-80.

Lindsay, C. and McQuaid, R. W. (2004). 'Avoiding the "McJobs": unemployed job seekers and attitudes to service work'. Work, Employment and Society, 18: 2, 297-318.

McDowell, L. (2002). 'Transitions to work: masculine identities, youth inequality and labour market change'. Gender, Place and Culture, 9: 1, 39-59. 
McDowell, L. (2003). 'Masculine identities and low-paid work: young men in urban labour markets'. International Journal of Urban and Regional Research, 27: 4, 828-848.

McQuaid, R. W. and Lindsay, C. (2002). 'The "employability gap": long-term unemployment and barriers to work in buoyant labour markets'. Environment and Planning C: Government and Policy, 20: 4, 613-628.

Newman, K. S. (1999). No Shame in My Game: the Working Poor in the Inner City, New York: Russell Sage Foundation.

Nickson, D., Warhurst, C., Cullen, A. and Watt, A. (2003). 'Bringing in the excluded? Aesthetic labour, skills and training in the "new" economy'. Journal of Education and Work, 16: 2, 185-203.

ONS (Office for National Statistics) (2004). New Earnings Survey (residence-based), at www.nomisweb.co.uk

Ritter, J. and Anker, R. (2002). 'Good jobs, bad jobs: workers' evaluations in five countries'. International Labour Review, 141: 4, 331-358.

Rose, M. (2003). 'Good deal, bad deal? Job satisfaction in occupations'. Work, Employment and Society, 17: 3, 503-530.

Sassen, S. (1996). 'Service employment regimes and the new poverty', in E. Mingione (ed), Urban Poverty and the Underclass, Oxford: Blackwell.

Scottish Executive (2001). Scottish Economic Report, Edinburgh: Stationery Office Scotland.

Scottish Executive (2004). Glasgow City Economic Briefing: April 2004, Edinburgh: Scottish Executive.

Sennett, R. (1998). The Corrosion of Character: the Personal Consequences of Work in the New Capitalism, London: Norton.

Singlemann, J. (1978). From Agriculture to Services: the Transformation of Industrial Employment, Beverley Hills: Sage.

Talwar, J. P. (2002). Fast Food, Fast Track: Immigrants, Big Business and the American Dream, Boulder, CA: Westview.

Taylor, P., Baldry, C., Ellis, V. and Bain, P. (2003). "“A unique working environment": health, sickness and management in UK call centres'. Work, Employment and Society, 17: $1,435-458$.

TERU (Training and Employment Research Unit) (1999). Jobs Growth: from Perception to Reality, Glasgow: University of Glasgow.

Warhurst, C. and Nickson, D. (2001). Looking Good, Sounding Right, London: Industrial Society.

Webster, D. (2000). 'The geographical concentration of labour market disadvantage'. Oxford Review of Economic Policy, 16: 1, 114-128.

Webster, J. (2004). 'Digitalising inequality: the cul-de-sac of women's work in European services'. New Technology, Work and Employment, 19: 3, 160-176.

Westwood, A. (2002). Is Neww Work Good Work?, London: Work Foundation. 